\title{
Observations on the Biology of the Pacific Sharpnose Shark (Rhizoprionodon longurio, Jordan and Gilbert, 1882), Captured in Southern Sinaloa, México
}

\author{
J. Fernando Márquez-Farias ${ }^{1}$ \\ Centro Regional de Investigación Pesquera de Guaymas, Instituto Nacional de la Pesca SAGARPA \\ Calle 20 Sur No. 605. Col. Cantera, CP8 85400, Guaymas, Sonora, Mexico \\ David Corro-Espinosa \\ Centro Regional de Investigación Pesquera de Mazatlán, Instituto Nacional de la Pesca \\ SAGARPA, Calzada Sábalo-Cerritos S/N. CP. 82010, Mazatlán, Sinaloa, Mexico \\ and

\section{J. Leonardo Castillo-Géniz ${ }^{2}$} \\ Centro Regional de Investigación Pesquera de Ensenada, Instituto Nacional de la Pesca \\ SAGARPA, Carretera Tijuana-Ensenada km. 97.5. CP. 22880, El Sauzal de Rodríguez \\ Ensenada, Baja California, Mexico
}

\begin{abstract}
Márquez-Farias, J. F., D. Corro-Espinosa, and J. L. Castillo-Géniz. 2005. Observations on the Biology of the Pacific Sharpnose Shark (Rhizoprionodon longurio, Jordan and Gilbert, 1882), Captured in Southern Sinaloa, México. J. Northw. Atl. Fish. Sci., 35: 107-114. doi:10.2960/J.v35.m506
\end{abstract}

\begin{abstract}
The Pacific sharpnose shark, (Rhizoprionodon longurio, Jordan and Gilbert, 1882), migrates along the Pacific coast of Mexico. It is captured with gillnets and bottom long lines commonly used in the artisanal fishery of Mazatlan. From a sample of 3464 individuals, $R$. longurio was observed to be a viviparous shark of small size, which is born at an average length of $31 \mathrm{~cm}$ total length (TL), after a gestation period of 10 to 11 months. The number of embryos showed no statistical relationship to the TL. The average number of embryos per female was $7.4(\sigma=2.01, n=146)$ and sex ratio was $1: 1$. Observations on the growth of the claspers indicated that male maturity begins at $93 \mathrm{~cm}$ TL. The two smallest gravid females measured were 83 and $87 \mathrm{~cm}$ TL. The rest of the gravid females were at least $92 \mathrm{~cm}$ TL. Between 90 and $95 \mathrm{~cm}$ TL, the females exhibited an increase in the width of the oviducal gland and its size ranged from 5 to $12 \mathrm{~mm}$. The statistical relationship between weight and length is presented in which females reach a larger size than males. The diet of $R$. longurio was composed principally of crustaceans and demersal teleost fishes.
\end{abstract}

Key words: Sharks, fisheries, life history, reproduction, diet, migration.

\section{Introduction}

The Pacific sharpnose shark (Rhizoprionodon longurio, Jordan and Gilbert, 1882) is a small species that inhabits the coastal waters of the eastern tropical Pacific ocean from southern California to Peru (Compagno, 1984). It is exploited commercially in the Pacific Ocean off Mexico from the Gulf of California to Puerto Madero, Chiapas (Castillo-Géniz et al., 1997). It frequents muddy bottom areas. It is not known whether it utilizes coastal lagoons as nursery areas, or if like R. terraenovae (Castillo-Géniz et al., 1998) its congener in the Atlantic, it utilizes only open waters.
The catch of $R$. longurio in southern Sinaloa shows a strongly seasonal pattern, which goes from November to April, with the maximum peak in February and moderate catches in the other months mentioned. This fishery is possible because of the massive movement of the species associated with changes in sea temperature, among other factors. It is observed that $R$. longurio is as vulnerable to gillnets as it is to bottom long lines. The shark fishery is typically artisanal (Castillo-Géniz et al., 1998), coastal and is conducted with fiberglass boats ("pangas") of 22-25 feet in length. The work of the fishery normally lasts from 12 to 24 hours. The number of crew members ranges from 2 to 3 , and the boats have a capacity of up to 1.5 tons.

\footnotetext{
${ }^{1}$ Present address: Centro Regional de Investigación Pesquera de Mazatlán, Instituto Nacional de la Pesca SAGARPA, Calzada Sábalo-Cerritos S/N. CP. 82010, Mazatlan, Sinaloa, Mexico

${ }^{2}$ Present address: CICESE. Km. 107 Carretera Tijuana-Ensenada, CP 22860. Ensenada, Baja California, Mexico
} 
Although sharks have been fished and landed in Sinaloa for many years, information about the species biology has been isolated and poorly documented. The present study has as its objective the review and analysis of some aspects of the biology of this species, which is one of the most important in the artisanal shark fishery in southern Sinaloa.

\section{Material and Methods}

A total of 3464 individuals of $R$. longurio were examined during the landing of fish in the artisanal shark fishery at the fishing camp at Playa Sur in Mazatlán, Sinaloa (Fig. 1) in the period 1987-99. The samples were taken in the principal fishing season for this species in southern Sinaloa, which takes place from November through April. Consistent with the recommendation of Compagno (1984), several different morphometric values were recorded. Total length (TL) was taken from the point of the snout to the extreme distal and of the caudal fin, by placing the specimen laterally in a natural position. The fork length (FL) was taken from the point of the snout to the posterior edge of the lower lobe of the caudal fin. When necessary, TL was estimated from FL, using the linear equation $\mathrm{TL}=4.6679+1.1538(\mathrm{FL}),\left(r^{2}=0.9479\right.$, $n=544$ ), as derived from the present study. All lengths measurements were made to the nearest centimeter. The recorded lengths were analyzed for the sexes combined, and frequency histograms were plotted. The relationship between weight and length was estimated for males, females (including gravid females), and the sexes combined. The model describing this relationship was typically of the form $W=a(\mathrm{TL})^{b}$, where $\mathrm{W}$ is the total weight ( $\left.\mathrm{kg}\right), a$ and $b$ are fitting constants.

Sexual maturity in males was estimated by observing the level of calcification of the claspers and the capacity for their rotation. The length of the claspers was taken from its anterior attachment at the cloaca to the distal tip of the claspers. Females were considered mature when they showed yellow ova in the ovary or evidence of pregnancy (i.e. blastodic capsules deposited in the uterus). The ova were counted and their diameter measured. The width of the oviducal gland was measured, for the purpose of analyzing changes in its size associated with sexual maturity and reproductive activity. Fecundity was estimated by examining the relationship between a female's length and the number of embryos per litter, and the weighted average value of pup numbers per litter was calculated. The sex ratio of the species was estimated using embryos in order to avoid the bias associated with sexual segregation commonly reflected in the landings in the fishery.

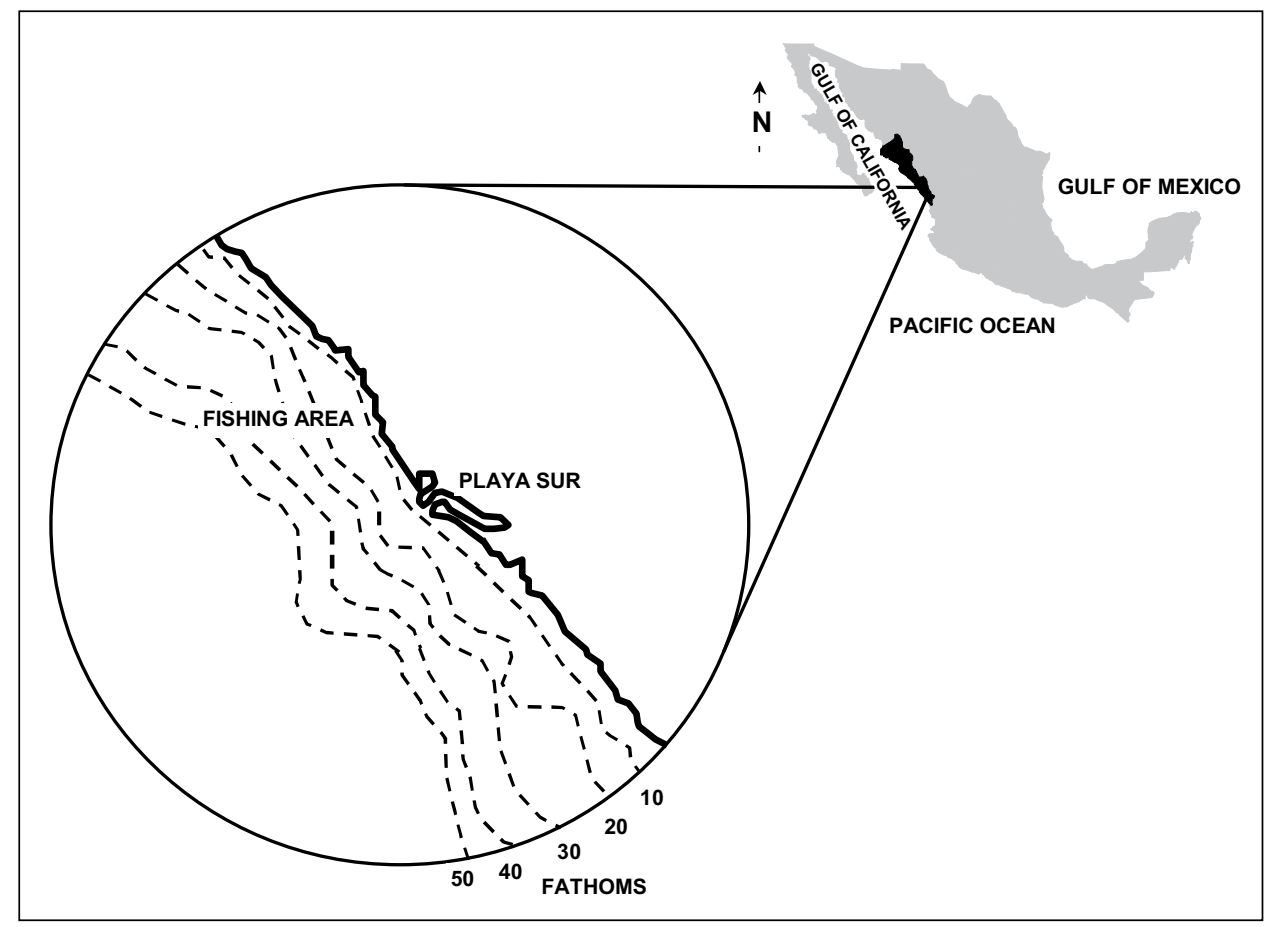

Fig. 1. Area of capture of the sharpnose shark, R. longurio, by the artisanal fishery in Mazatlán, Sinaloa. 
The diet of $R$. longurio was studied through stomach content analysis, by means of the methods of frequency of occurrence, percent volume, numerical abundance (Holden and Raitt, 1975) and the Index of Relative Importance (IRI) (Pinkas et al., 1971). The relationship was $I R I=(N+V) F$, where $N$ is the percentage of each prey by number, $V$ is the percentage of prey by volume, and $F$ is the percentage of frequency of occurrence.

\section{Results}

\section{Length Structure}

The length frequency distribution shows a sudden increase after $85 \mathrm{~cm}$ TL (Fig. 2). Only 19\% of the individuals measured were smaller than this, and this is indicated by a small component of juveniles with a mode at $70 \mathrm{~cm}$ TL. There were also two modal groups of adults observed at 96 and at $108 \mathrm{~cm}$ TL. Females reached longer lengths than males. The maximum length recorded from the sample was a female specimen at $129.5 \mathrm{~cm}$ TL.

\section{Length-weight relationship}

The length-weight relationships were estimated for both sexes and sexes combined. The values of the constants in the equation $W=a(\mathrm{TL})^{b}$ that describes the length-weight relationship were as follows: for females, $a=0.00000023, b=3.6339, r^{2}=0.9478(n=112)$; for males, $a=0.00000074, b=3.3697, r^{2}=0.9065(n=101)$; for both sexes, $a=0.00000035, b=3.5394, r^{2}=0.9326$ $(n=213)$.

The scatter diagram for the length-weight relationship of females and males (Fig. 3) as well as fitted curve for both sexes (not shown in Fig. 3), shows that the specimen with the greatest weight was a female of $123 \mathrm{~cm} \mathrm{TL}$ and $12 \mathrm{~kg}$, while the heaviest male measured $113 \mathrm{~cm} \mathrm{TL}$ and weighed $6.3 \mathrm{~kg}$.

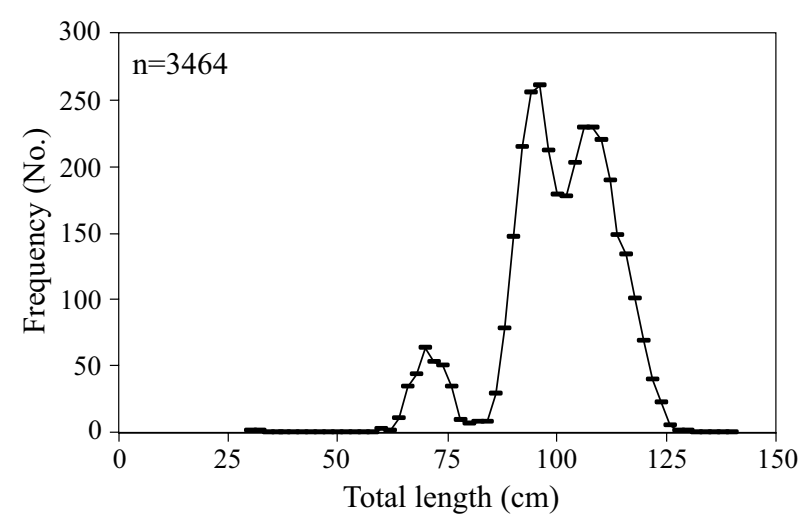

Fig. 2. Length frequency distribution of the sharpnose shark, $R$. longurio captured in southern Sinaloa, Mexico.

\section{Sexual maturity}

Males. The early development of the claspers was gradual. They appeared flaccid in juvenile specimens and began to grow rapidly once the males reached $80 \mathrm{~cm} \mathrm{TL}$ (Fig. 4). The calcification of the claspers was observed from $96 \mathrm{~cm}$ TL on. Specimens of $80-95 \mathrm{~cm}$ were at a stage of transition from immaturity to maturity. They were individuals with partially calcified claspers, which eventually were able to bend. The smallest mature male, with calcified claspers, measured $93 \mathrm{~cm}$ TL. All males larger than $97.2 \mathrm{~cm}$ TL were mature and showed calcified claspers with a capacity for forward rotation.

Females. Since the capture of $R$. longurio is seasonal, few females with mating scars could be recorded. An exponential relationship between the growth in width of the oviducal gland and the length of females was observed (Fig. 5). The oviducal gland grows slightly until a female reaches $85 \mathrm{~cm}$ TL; while between 90 and $95 \mathrm{~cm}$ TL, the width of this gland grows abruptly and can register 5 to $12 \mathrm{~mm}$. The maximum width of this gland was $22 \mathrm{~mm}$. In

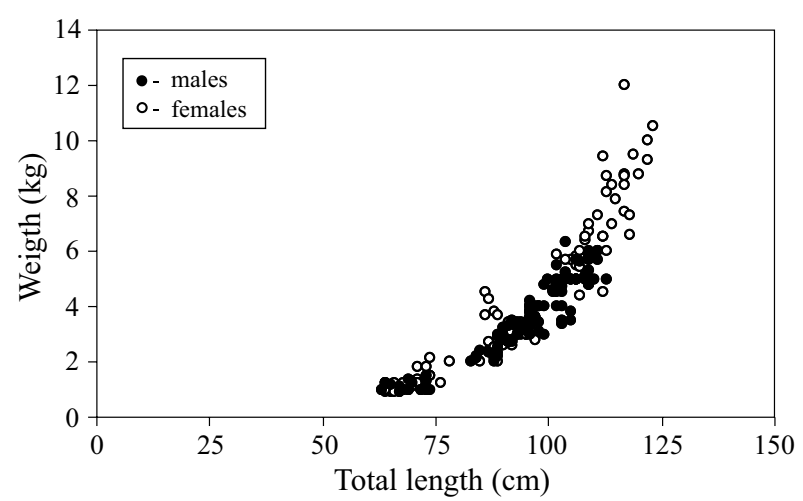

Fig. 3. Relationship between the total weight and total length of females and males of $R$. longurio.

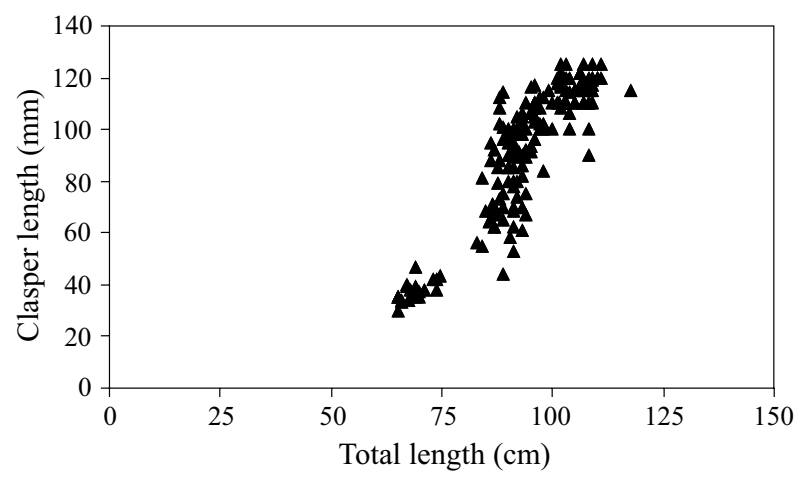

Fig. 4. Relationship between the length of the clasper and the total length of $R$. longurio. The arrow shows the change of the slope of the clasper that represents mature individuals 


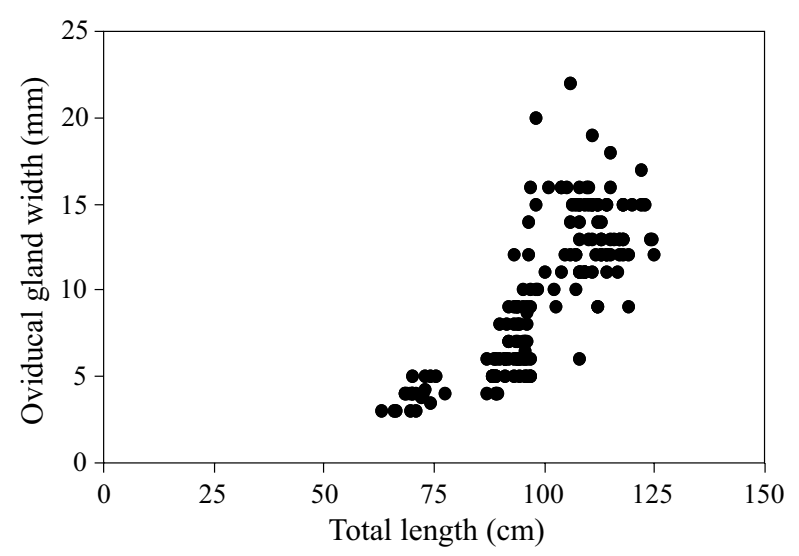

Fig. 5. Relationship between the oviducal gland width and total length of $R$. longurio.

mature specimens, the measurement of the oviducal gland was variable and dependent upon ovulation. The rest of the gravid females were at least $92 \mathrm{~cm} \mathrm{TL}$.

\section{Fecundity}

No statistical correlation was found between length of a female and the number of embryos. Nor was any relationship found between the length of a female and the size of the embryos. The smallest gravid females measured 83 and $87.5 \mathrm{~cm}$ TL and carried 6 and 8 embryos, respectively. The length interval for gravid females was from 83 to $125 \mathrm{~cm}$ TL (Fig. 6). The frequency distribution of the number of embryos per female was of a normal type. Broods examined ranged from 1 to 12, with an average of 7.4 and $\sigma=2.01(n=146)$ (Fig. 7). Sex ratio of embryos was 1:1.

\section{Embryonic development}

The development of embryos of the species is through placental viviparity. Females were observed that held embryos in their final phase of development at the same time as mature ova in the ovary, suggesting that the species reproduces every year. In some cases, differential growth of embryos was observed in each uterus and among uteri (Fig. 8).

In our samples no embryo with a length less than $14 \mathrm{~cm}$ TL was observed in any female. Females examined in January contained embryos with lengths between 15 and $31 \mathrm{~cm} \mathrm{TL}$ and an average of $28 \mathrm{~cm}(\sigma=4.05, n=$ 47); in February, the TL interval was $21-32 \mathrm{~cm}$ with an average of $28 \mathrm{~cm}(\sigma=2.56, n=134)$ and in March, the TL interval of the embryos was $19-37 \mathrm{~cm}$, with an average length of $31 \mathrm{~cm}(\sigma=3.14, n=155)$. Consistent with the growth of the embryos, the estimated gestation time would be $10-12$ months. Birth size is approximately $31 \mathrm{~cm} \mathrm{TL}$,

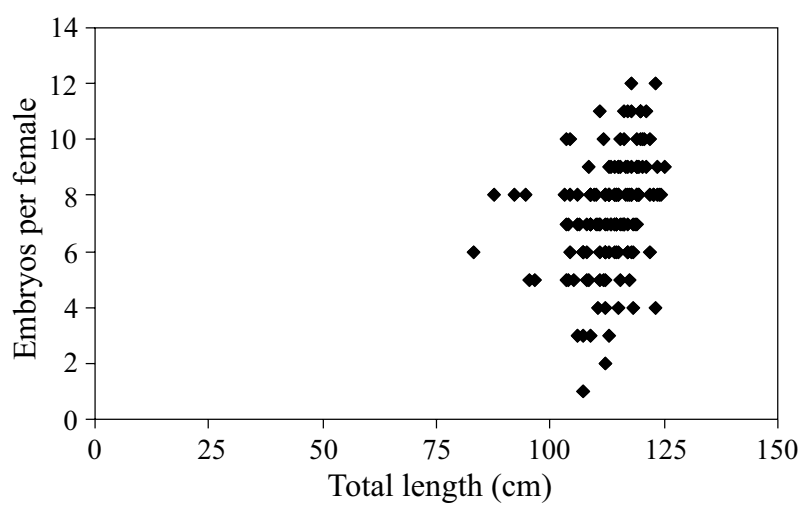

Fig. 6. Relationship between fecundity (embryos per female) and the total maternal length of $R$. longurio.

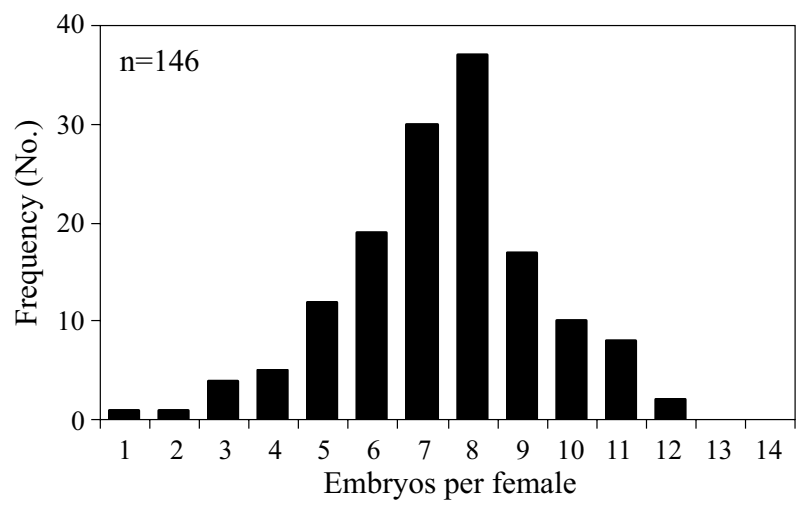

Fig. 7. Frequency distribution of embryos per female.

and the birth season extends from the beginning of April until the end of June. Pregnant females carrying full term embryos have been recorded in the Gulf of California, particularly from the middle and upper Sonora coast line (Márquez-Farias, Instituto Nacional de la Pesca, Mexico, personal observations).

\section{Feeding}

Of the 82 specimens of $R$. longurio whose stomach contents were examined, 57 were females with a size range of 84-118 cm TL and the other 25 were males with TL between 91 and $110 \mathrm{~cm}$. The stomachs of most specimens were empty (36.6\%). Food items included three taxonomic groups: 1) teleosts, which was the group most important in number, volume and occurrence; 2) cephalopods, which constituted the second most important group of prey, and of those that could be identified from the presence of mandibles, the family Loliginidae, as well as the species Loliolopsis diomedae, and 3) crustaceans, of which the remains of three exoskeletons in an advanced stage of digestion were found (Table 1). 


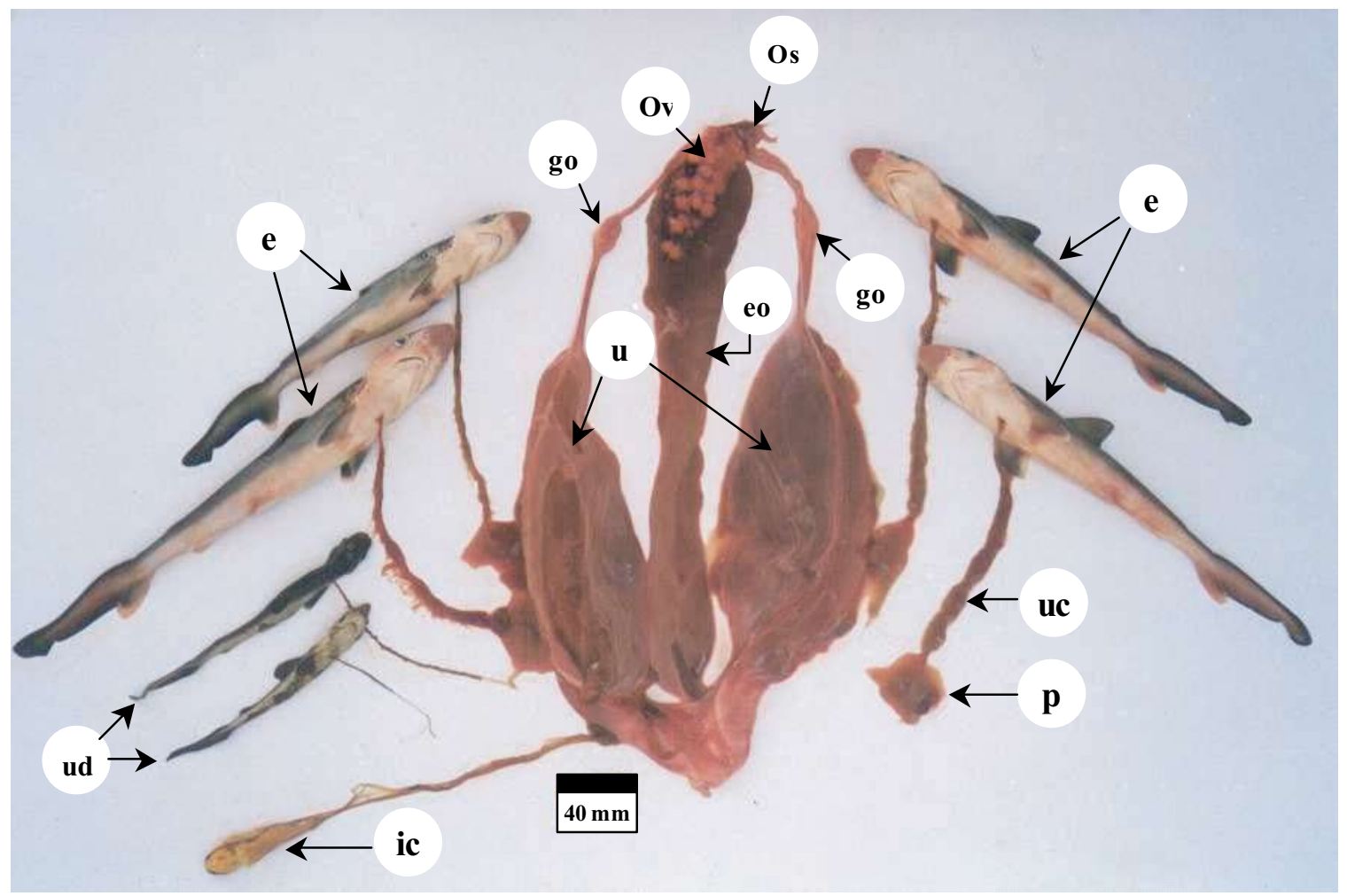

Fig. 8. Reproductive apparatus of a pregnant female of $R$. longurio. Uteri (u); Ostium (Os) or bifurcation of the upper oviducts through which pass the ova toward the oviducal gland (go). Ovary (Ov) containing absorbed eggs. The embryos (e) were dissected from the uterus. Two undeveloped embryos are shown (ud). The embryos are connected to the uterus by a similar placenta (p) and the umbilical cord (uc) which reaches to the embryo and through which the embryo is nourished. The connection of the umbilical cord and the embryo is on the ventral side, in the middle of the pectoral fins of the embryo. In viviparous species, at birth the umbilical cord is burst, causing the opening which distinguishes recently born individuals. Infertile capsule (ic). Epigonal organs (eo). Photography by David Corro Espinosa.

\section{Discussion}

Studies of the Pacific sharpnose shark, $R$. longurio, are scarce. Most of them refer to lists of fauna in which their distribution and abundance in the catches of artisanal fisheries or in research cruises are mentioned (Hubbs and McHugh, 1950; Castro-Aguirre, 1967; Kato et al., 1967; Kato and Hernández, 1967; Applegate et al., 1979; Amezcua-Linares, 1996). Information on the basic biology of the species is summarized by Castro (1983) and Compagno (1984), but has not been updated. Rhizoprionodon longurio frequents sandy bottoms and is highly vulnerable to gillnets. In Mazatlán, it is an important part of the catches of artisanal shark fisheries. It provides an opportunity, as already indicated, for a highly seasonal fishery, since the species undertakes extensive migrations and is not available in the study area in the period May-November. Kato and Hernández (1967) reported the movement of a specimen of this species that was tagged opposite Cabo San Lucas, B.C.S. and recaptured four months later 600 miles to the north, to the west of the Peninsula of Baja California. Similar major movements have been reported for the Atlantic sharpnose shark, $R$. terraenovae in the Gulf of Mexico (Márquez-Farias and Castillo-Géniz, 1998). North-south movements are found also in the Upper Gulf of California (MárquezFarias et al., 1999). From our perspective, the migration scheme indicates winter-spring movements of the population from southern Isla Tiburón in the central Gulf of California to the southern region of the state of Nayarit along the eastern shore of the Gulf (Castillo-Géniz, 1990). In the period summer-autumn, the species moves in an opposite direction either through the central axis of the Gulf of California or along the Sonora coast line until reaching its place of origin including the Upper Gulf of California (Cudney-Bueno and Turk-Boyer, 1998). These authors report nurseries of $R$. longurio in the Upper Gulf of California and recognize a reproductive season from 
TABLE 1. List of the taxa found in the digestive tracts of 82 specimens of $R$. longurio examined by the third author (Castillo-Géníz, 1990) in the fishing camp at Playa Sur in Mazatlán, Sinaloa, Mexico. IRI = Index of Relative Importance. Due to the reduced weight and volume of the mandibles of squid $(<0.1 \%)$, the value of $0.1 \%$ was assigned to them for the calculation of IRI recommended by Brodeur et al. (1987). ( $\mathrm{N}$ is the percentage of each prey by number, $\mathrm{V}$ is the percentage of prey by volume, $\mathrm{F}$ is the percentage of frequency of occurrence.)

\begin{tabular}{|c|c|c|c|c|c|c|c|c|}
\hline Prey items & $\begin{array}{l}\text { ber of items } \\
(\mathrm{N})\end{array}$ & $\% \mathrm{~N}$ & $\begin{array}{c}\text { Volume (ml) } \\
\text { (V) }\end{array}$ & $\% \mathrm{~V}$ & $\begin{array}{c}\text { Occurrence } \\
\text { (F) }\end{array}$ & $\% \mathrm{~F}$ & IRI & $\%$ IRI \\
\hline Crustacea & 3 & 4.92 & 5.8 & 0.70 & 3 & 5.77 & 33.35 & 0.007 \\
\hline Isopoda & 1 & 1.64 & 2.0 & 0.24 & 1 & 1.92 & 3.7 & 0.001 \\
\hline \multicolumn{9}{|l|}{ Cephalopoda } \\
\hline Decapoda & 1 & 1.64 & 0.1 & $0.1^{*}$ & 1 & 1.92 & 3.45 & 0.001 \\
\hline Loligínidae & 1 & 1.64 & 0.1 & $0.1^{*}$ & 1 & 1.92 & 3.45 & 0.001 \\
\hline Loliolopsis diomedae & 1 & 1.64 & 0.1 & $0.1^{*}$ & 1 & 1.92 & 3.45 & 0.001 \\
\hline \multicolumn{9}{|l|}{ Octopoda } \\
\hline Octopodidae & 1 & 1.64 & 0.1 & $0.1 *$ & 1 & 1.92 & 3.45 & 0.001 \\
\hline \multicolumn{9}{|l|}{ Bothidae } \\
\hline Syacium ovale & 1 & 1.64 & 1.0 & 0.12 & 1 & 1.92 & 3.47 & 0.001 \\
\hline Clupeidae & 2 & 3.28 & 16.5 & 2.01 & 2 & 3.85 & 20.69 & 0.004 \\
\hline Gerreidae & 1 & 1.64 & 30.0 & 3.66 & 1 & 1.92 & 10.27 & 0.002 \\
\hline Muraenidae & 4 & 6.56 & 122.0 & 14.9 & 2 & 3.85 & 86.16 & 0.019 \\
\hline \multicolumn{9}{|l|}{ Sciaenidae } \\
\hline Bairdiella sp. & 1 & 1.64 & 27.0 & 3.29 & 1 & 1.92 & 9.56 & 0.002 \\
\hline Larimus sp. & 1 & 1.64 & 14.0 & 1.71 & 1 & 1.92 & 5.32 & 0.001 \\
\hline \multicolumn{9}{|l|}{ Serranidae } \\
\hline Diplectrum sp. & 8 & 13.11 & 203.0 & 24.81 & 7 & 13.46 & 516.31 & 0.112 \\
\hline \multicolumn{9}{|l|}{ Synodontidae } \\
\hline Synodus sp. & 2 & 3.28 & 49.0 & 5.98 & 2 & 3.85 & 36.94 & 0.008 \\
\hline Unidentified teleost & 29 & 47.54 & 308.9 & 37.7 & 23 & 44.23 & 3841.37 & 0.831 \\
\hline Unidentified birds & 1 & 1.64 & 22.0 & 2.68 & 1 & 1.92 & 8.39 & 0.002 \\
\hline \multirow[t]{2}{*}{ Unidentified remains } & 3 & 4.92 & 7.0 & 0.85 & 3 & 5.77 & 34.21 & 0.007 \\
\hline & 61 & & & & 52 & & & \\
\hline
\end{tabular}

March to June peaking in April, which is consistent with our observations of unavailability of pregnant females carrying full-term embryos in Mazatlán.

\section{Lengths and weights of the catch}

Most of the lengths of specimens observed in this study were of mature individuals. The peaks in the frequency distribution, more than representing an actual distribution structure of lengths from the fraction of the population, are believed to be caused by the high selectivity of gillnets (Kirkwood and Walker, 1986). This effect of selectivity could have excluded smaller individuals from the catches.

In most other species of sharks, females reach larger sizes than males (Castro, 1993 and 1996) it was observed that in $R$. longurio females reach a greater length than males. Consistent with Kohler et al., (1995), the factors that can affect the weight of sharks of the same size are principally the quantity of stomach contents, the state of maturity, and the condition of the shark. Between females and males, the differences observed in this study were due, in large part, to the presence of gestating females in the samples, specifically due to the number of embryos and their stage of development.

\section{Reproduction}

The appearance of seminal fluid and the developmental condition of the clasper was found to help determine the length at sexual maturity. In the present study, the development of the clasper was initially gradual and increased exponentially resulting in the relationship of clasper length to TL showing a typical sigmoid curve. The 
upper inflection of the trend line shows when individuals reached sexual maturity. The verical trend of the TL and clasper length relationship refers to specimens in the transition stage between immaturity and maturity (Pratt (1979; Castro, 1996).

In $R$. longurio, the ovary is of an external type (Pratt, 1988) and, as has been reported for other carcharhinids, only one is functional. The number of ova observed in the ovary was proportional to the average number of embryos. No direct relation was shown between the number of embryos and the length of the female. It has been suggested that this relationship exists, but it has been observed only in few shark species.

Castro and Wourms (1993) report that $R$. terraenovae mates a short time after parturition, thus females have mature ova in the ovary at the same time as embryos in the final phase of development. Simpfendorder (1992) reported that Rhizoprionodon taylori reproduced annually in the spring and gestation took 11.5 months. Because of the migratory movements of $R$. longurio, only females with embryos in an advanced stage of development were observed in this study. Therefore, the estimation of the period of gestation presented here (10-12 months) ought to be taken with caution given that the embryonic curve was estimated without the complete cycle of embryonic growth being observed. Migrations also made it difficult to clarify the frequency of the reproductive cycle of the species. Specific studies on this matter are recommended.

The degree of scatter in the relationship between the length of females and the width of the oviducal gland was because some females were found in reproductive activity while others were at rest. Since the width of the oviducal gland is related to the reproductive activity of females, the scattering was less evident in the juveniles. This offset reflects different sizes of the oviducal gland in mature females of the same lengths (Fig. 5). It is not known whether $R$. longurio utilizes a strategy of storing sperm in the oviducal gland. In agreement with Pratt (1993), such observations could assist in elucidating the reproductive strategy of the species.

The mean fecundity of $R$. longurio was 7.4 embryos per female (Fig. 7), greater than that reported for $R$. terraenovae at 5.3 (Márquez-Farias and Castillo-Géniz, 1998). It is recognized that there exists a potential bias in estimating the fecundity from the count of embryos in an intermediate and advanced state of development, given that it has been documented that females generally abort some embryos in the struggle at the time of capture (Castro, 1993). Thus, it is advisable to base the observation of fecundity also on females that have embryos in early stages of development or on placental scars.

As the literature notes, $R$. terraenovae and $R$. taylori are species with high intrinsic rates of population increase (Walker, 1998, Cortés, 2002). The biological productivity among species of the same genus can be compared in modeling their demographics, incorporating information on survival, on the reproductive cycle, fecundity and sizeat-maturity (Cortés, 1998, Au and Smith, 1998). It would not be surprising if $R$. longurio fell in the category of either moderately or highly productive species.

\section{Diet}

The diet of $R$. longurio was dominated by small teleost fishes, serranids of the genus Diplectrum and crustaceans (Table 1). Simpfendorfer and Unsworth (1998) reported a similar diet for individuals of $R$. taylori in the north of Queensland, Australia. Gómez and Bashirulah (1984) reported that crustaceans and fish were the principal food of Rhizopionodon porosus in the waters of eastern Venezuela. The size of sample used for the analysis of stomach contents in this study is not sufficient for generalizing about the feeding habits of $R$. longurio. However, it is recognized that its diet is based on species of demersal habitats.

\section{Acknowledgements}

We express our gratitude to Michael L. Weber for taking his valuable time to translate the earlier manuscript. We accept any responsibility for language misinterpretation, if it is the case. We express our appreciation to all of the artisanal fishermen at the fishing camp at Playa Sur in Mazatlán, Sinaloa, for their cooperation in our work at the camp. Thanks are also given to the students of University of Sinaloa for their valuable participation during sampling. The Instituto Nacional de la Pesca of Mexico financed this study.

\section{References}

AMEZCUA-LINARES, F. 1996. Peces Demersales de la Plataforma Continental del Pacífico Central de México. ICMyL, UNAM, CONABIO. Interlínea. Primera Edición. México, D. F., 184 p.

APPLEGATE, S. P., L. ESPINOSA, L. MENCHACA, and F. SOTELO. 1979. Tiburones Mexicanos. Subsecretaría de Educación e Investigación Tecnológica, Dir. Gen. Cienc. Tec. de Mar, S.E.P. Primera edición. México, D.F., 147 p.

AU, D. W., and S. E. SMITH. 1998. A demographic method with population density compensation for estimating productivity and yield per recruit of the leopard shark Triakis semifasciata. Can. J. Fish. Aquat. Sci. 54: 415-420.

BRODEUR, R, H. LORZ, and E. PEARCY. 1987. Food habits and dietary variability of pelagic nekton off Oregon and 
Washington. 1979-1984. NOAA Tech. Rep., NMFS, 57: $37 \mathrm{p}$.

CASTILLO-GÉNIZ, J. L. 1990. Contribución al conocimiento de la biología y Pesquería del cazón bironche, Rizoprionodon longurio (Jordan y Gilbert, 1882) (Elasmobranquii, Carcharhinidae), del Sur de Sinaloa, México. Tesis Profesional. Facultad de Ciencias, U.N.A.M., 128 p.

CASTILLO-GÉNIZ, J. L., J. F. MÁRQUEZ-FARIAS., A. CID DEL PRADO V., S. R. SORIANO V., and S. C. RAMÍREZ. 1997. Descripción, evaluación y manejo de la pesquería artesanal de tiburón de Puerto Madero, Chiapas. Informe Técnico del Instituto Nacional de la Pesca, 34 p.

CASTILLO-GÉNIZ, J. L., J. F. MÁRQUEZ-FARIAS., M. C. RODRÍGUEZ DE LA CRUZ, E. CORTÉS, and A. CID DEL PRADO. 1998. The Mexican artisanal shark fishery in the Gulf of Mexico: towards a regulated fishery. Mar. Freshw. Res., 49: 611-620.

CASTRO-AGUIRRE, J. L. 1967. Contribución al estudio de los tiburones de México. Tesis Profesional. Esc. Nal. Cienc. Biol., Instituto Politécnico Nacional, México, D. F., 258 p.

CASTRO, J. I. 1983. The Sharks of North American Waters. Texas A \& M University Press, College Station, Texas, U. S. A., 179 p.

1993. The biology of the finetooth shark, Carcharhinus isodon. Environ. Biol. Fish., 36: 219-232.

CASTRO, J. I., and J. P. WOURMS. 1993. Reproduction, placentation, and embryonic development of the Atlantic sharpnose shark, Rhizoprionodon terraenovae. J. Morphol., 218: $257-80$.

CASTRO, J. I. 1996. Biology of the blacktip shark, Carcharhinus limbatus, off the southeastern United States. Bull. Mar. Sci., 59(3): 508-522.

COMPAGNO, L. J. V. 1984. FAO species Catalogue. Vol. 4 Sharks of the World. Anannotated and illustrated catalogue of shark species known to date. Part 2. Carcharhiniformes. FAO Fish. Synop., (125) Vol. 4, Part 2: 251-655.

CORTÉS, E. 1998. Demographic analysis and shark stock assessment and management. Fish. Res., 39: 199-208.

2002. Incorporating uncertainty into demographic modeling: Application to shark populations and their conservation. Conserv. Biol. 16(4): 1048-1062.

CUDNEY-BUENO, R. Y., and P. J. TURK-BOYER. 1998. Pescando Entre Mareua del Alto Golfo de California: Una Guía Sobre la Pesca Artesenal, Su Gente y Sus Porpuestas de Manejo, CEDO Intercultural, Puerto Peñasco, Sonora, México, 1-166 p.

GÓMEZ, F. E., and A. K. M. BASHIRULAH. 1984. Relación longitud-peso y hábitos alimenticios de Rhizoprionodon porosus, Poey 1861 (Fam. Carcharhinidae) en el Oriente de Venezuela. Bol. Inst. Oceanogr. Venez. Univ. Oriente, 23(1 and 2): 49-54.

HOLDEN, M. J., and D. S. RAITT. 1975. Manual de Ciencias
Pesqueras. Parte 2. Métodos para investigar los recursos y su aplicación. Doc. Téc. Pesc. FAO, 115(1): 211 p. (Spanish).

HUBBS, C. L., and J. L. MCHUGH. 1950. Pacific Sharpnose shark, Scoliodon longurio, in California and Baja California. Calif. Fish. Game, 36: 7-11.

JORDAN D. S. and C. H. GILBERT. 1882. Descriptions of thirty-three new species of fishes from Mazatlán, Mexico. Proc. U. S. Nat. Mus., 5: 377-614.

KATO, S., and A. HERNÁNDEZ C. 1967. Shark tagging in the eastern Pacific Ocean, 1962-65. In: Sharks, skates and rays. P. W. Gilbert, R. F. Mathewson and D. P. Rall (eds.). Johns Hopkins Press, Baltimore, Maryland, USA: 93-109.

KATO, S., S. SPRINGER, and M. H. WAGNER. 1967. Field guide to eastern Pacific and Hawaian Sharks. U. S. Fish. Wild. Serv. Circ., 271: 42 p.

KIRKWOOD, G. P., and T. I. WALKER. 1986. Gill net mesh selectivities for gummy shark, Mustelus antarcticus, Günter, taken in Southeastern Australian waters. Aust. J. Mar. Freshwat. Res., 37: 689-697.

KOHLER N. E., J. G. CASEY, and P. A. TURNER. 1995. Length-weight relationships for 13 species of sharks from the western North Atlantic. Fish. Bull., 93: 412-418.

MÁRQUEZ-FARIAS, J. F., and J. L. CASTILLO-GÉNIZ. 1998. Fishery biology and demography of the Atlantic sharpnose shark, Rhizonprionodon terraenovae, in the southern Gulf of Mexico. Fish. Res., 39: 183-198.

MÁRQUEZ-FARIAS, J. F., J. P. TYMINSKI, R. E. HUETER, J. L. CASTILLO-GENIZ, and C. MURILLO. 1999. Diversidad de elasmobranquios en Sonora, estimada de una prospección de la pesquería artesanal. Memorias I Simposium Internacional sobre el Mar de Cortés. 25-28 Mayo 1999. CICTUS. Hermosillo, Sonora. (Resumen).

PINKAS, L., M. S. OLIPHANT, and I. L. IVERSON. 1971. Food habits of albacore, bluefin tuna and bonito in California waters. Calif. Dep. Fish. Game. Fish. Bull., 152: 1-105.

PRATT, H. L. 1979. Reproduction in the blue shark. Prionace glauca. Fish. Bull., 77(2): 445-470.

1988. Elasmobranch gonad structure: A description and survey. Copeia, 1988: 719-729.

1993. The storage of spermatozoa in the oviducal glands of western North Atlantic sharks. Environ. Biol. Fish., 38: 139-149.

SIMPFENDORFER, C. A. 1992. Reproductive strategy of the Australian sharpnose ahark, Rhizoprionodon taylori (Elasmobranchii: Carcharhinidae), from Cleveland Bay, northern Queensland. Aust. J. Mar. Freshw. Res., 43: 67-75.

SIMPFENDORFER, C. A., and P. UNSWORTH. 1998. Reproductive biology of the whiskery shark, Furgaleus macki, off south western Australia. Mar. Freshw. Res., 49: 687-93.

WALKER, T. I. 1998. Can shark resources be harvested sustainably? A question revisited with a review of shark fisheries. Mar. Freshw. Res., 49: 553-572. 